\title{
Undergraduate Students' Attitude Towards Learning English: A case Study at Nong Lam University
}

\author{
Vo Van Viet* \\ Nong Lam University, ........... Vietnam \\ Received 30 November 2017 \\ Revised 15 December 2016; Accepted 25 December 2017
}

\begin{abstract}
Effective learning a second language is influenced by many factors. Among of those, attitude has been identified as an important one. Better understanding of students' attitude will help language teaching programmers, school managers and educators to develop strategies to improved student's learning outcomes. The drive of this study is to explore students' attitude toward learning English. Data were collected through a questionnaire from a total of 694 students at Nong Lam University. The results of the study showed that the students have positive attitude toward learning English as a foreign language.
\end{abstract}

Keywords: Attitude, student, English.

\section{Introduction}

English has become a language of international communication, a language of business, banking and finance, science and technology, cultural exchange and international relations worldwide. Many studies have shown that people are interested in a particular second language when they see that the language is a tool to achieving high economic status, ensuring life and satisfying one's life values. Practice has shown that proficiency in English is the key to success in life. Learner's attitude towards learning languages is one of the crucial factors determining the success or failure.

Attitude is considered as an important concept to understand human behavior and is defined as a mental state includes beliefs and feelings (Latchanna, G. \& Dagnew, A, 2009).

\footnotetext{
Tel: :....

Email: vietvovan@yahoo.com

https://doi.org/10.25073/2588-1159/vnuer.4119
}

Belief is an important factor determining achievement in language learning. If learners believe that they cannot do well, then that belief would be a major obstacle to successful learning a language (Lennartsson, 2008). Negative attitudes can hinder learning. However, a negative attitude can be changed and turned into a positive attitude, a positive outcome. Attitude is considered an important factor affecting language learning. Positive attitude towards learning languages is a good starting point to learn a language. Language attitudes, according to (Crystal, 1997), are the feelings people have about their own language or language of others.

In Vietnam, although English has become a compulsory subject for higher education academic programs throughout the country, but it can be said that the effectiveness of teaching and learning has not met any expectations. Researchers and educational administrators are very much concerned about how to improve the quality of teaching and learning. In the context 
of ongoing changes in the theory and methodology of teaching, the students (not the teachers) have the central role and attitudes of learners hold important positions in improving effective teaching and learning. Understanding the motivation, attitudes of learners will help curriculum developers design programs that meet objectives of the students and improve the academic achievement. From the above situation and context, this study was conducted to explore the attitude of students towards learning English, a survey at Nong Lam University Ho Chi Minh City, Viet Nam.

\section{Methodology}

This study used quantitative approach. Primary data for the research was collected through questionnaires. The questionnaire consists of two independent sections including demographic profile questions, attitude questions. Attitude items were selected and adjusted from survey instruments developed by Samar Rukh (2014) and Sk. Abdullah al Mamun et al. (2012). Participants were asked to rate each statement by their level of agreement in a close ended 5-level Likert scale with $5=$ strongly agree, $4=$ agree, $3=$ Normal, $2=$ disagree, $1=$ strongly disagree. NonProbability Sampling, or convenience sampling has been adopted to select participants for the study. A total of 694 useable questionnaires returned and used for the analysis. Data were analyzed using the Statistical Package for the Social Sciences (SPSS ${ }^{\circledR}$ Version 22.0 for Windows). Descriptive statistics was conducted to determine the frequency, the mean, and the standard deviation of the demographic profile and attitudinal data.

Because the study was conducted only at Nong Lam University based in Ho Chi Minh City, so the research findings provide only partial pictures about the students' attitudes toward learning English. Furthermore, data for the research based mainly on respondents' opinion about the statements in the questionnaire, so the assumption is that students have answered honestly and forthrightly.

\section{Definition of language attitude}

Attitude is main concept of social psychology. Attitudes towards language are the feelings about one's language and the languages of others (Crystal 1997). Linguistic behavior can be explained by language attitude. According to Baker (1992) the restoration, preservation or death in the life of the language depends fundamentally on the attitudes of people towards that language.

Many studies have focused on the three components of attitude include cognitive, emotional and behavioral. Component "cognitive" refers to any information, fact or knowledge relevant to an attitudinal subject includes the thoughts, beliefs and values of a language. Component "emotional" or "feelings" is comments (positive or negative) about the language (Baker, 1992; Rajecki, 1982). Third component is "behavior", a behavioral intention or the action can be done (possible acts) for the language (Rajecki, 1982). These three components have a reciprocal influence (Wenden, 1991).

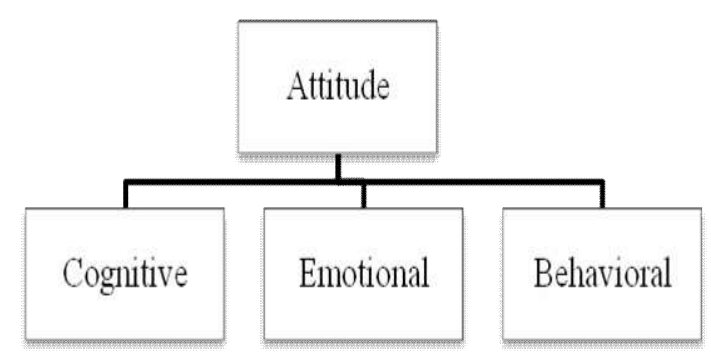

Source: (Hilgard, 1980)

\section{Result and discussion}

Demographic profile 
Table 1. Demographic profile of the sample

\begin{tabular}{llcc}
\hline Items & & Frequency & Percentage \\
\hline Gender & Female & 422 & 60,8 \\
& Male & 272 & 39,2 \\
\hline Year of study & & \\
& Freshman & 121 & 17,4 \\
& Sophomore & 259 & 37,3 \\
Junior & 248 & 35,7 \\
Senior & 63 & 9,1 \\
Others & 3 & 4 \\
\hline Time began to study & & \\
From primary school & 227 & 32,7 \\
From secondary school & 438 & 63,1 \\
From high school & 9 & 1,3 \\
From college & 20 & 2,9 \\
\hline Taking extra English courses & & \\
No & 434 & 62,5 \\
Yes & 260 & 37,5 \\
\hline Self- Assessment of English Skill & & \\
Very bad & 85 & 12,2 \\
Bad & 236 & 34,0 \\
Fairly Good & 347 & 50,0 \\
Very good & 24 & 3,5 \\
Excellent & 2 & 0,3 \\
\hline & & \\
\hline
\end{tabular}

The total number of respondents of this study was 694. The distribution of sample of the study is shown in Table 1 . The profile of respondents was described as follows:

Gender: Respondents were asked to state their gender. The analysis of the demographic variables indicates that there are more female than male respondents. The numbers of male and female in the sample were accordingly 272 (39.2\%) and $442(60.8 \%)$.

Years of study: Respondents were asked to indicate their year of study. There were $17.4 \%$ freshman $(n=17,4), 37.3 \%$ Sophomore $(n=259)$, $35.3 \%$ Junior $(\mathrm{n}=248), 9.1 \%$ senior $(\mathrm{n}=63)$ and others $0.4 \%(n=3)$.

The questionnaire also inquired about the time began to study English of each student. 227 respondents (32.7\%) have been studying English from primary school; 438 respondents $(63.1 \%)$ from secondary school; 9 respondents $(1.3 \%)$ from high school; 20 respondents $(2.9 \%)$ from college. Two hundred sixty respondents $(37,5 \%)$ said that they are taking extra English courses besides the college curriculum. 434 respondents $(62.5 \%)$ are not taking any extra English courses.

Respondents were also asked to assess their English skill. A half of respondents, fifty percent $(n=347)$, have classified as fairly good at English; 321 respondents classified as bad and very bad.

\section{Exploratory Factor Analysis (EFA)}

Factor analysis is used to identify latent constructs or factors. It is commonly used to reduce variables into a smaller set to save time and facilitate easier interpretations. In this study, EFA have been conducted in 22 items (observable variables) to be reduced to three latent variables that share a common variance and are unobservable.

The example is suitable for EFA as the KMO is $0.883>0,5$. Noted that, the Kaiser Criterion is said to be reliable when: a) the averaged extracted communalities is at least 
more than .70 and when there are less than 30 variables, or b) the averaged extracted communalities is equal or above .60 and the sample size is above 250 cases (Field, 2009).

The result of EFA with Principal Components analysis is used to extract maximum variance from the data set with each component thus reducing a large number of variables into smaller number of components and Varimax rotation with Kaiser Normalization resulted in three factors with extracted variance is $50,02 \%>50 \%$. The first factor includes 9 items named emotional factor. The second factor includes 9 items named cognitive factor. The last factor includes 4 items named behavioral factor. The result of final EFA was presented in table 2.

Table 2. EFA

\begin{tabular}{|c|c|c|c|}
\hline \multirow{2}{*}{ Items } & \multicolumn{3}{|c|}{ Factors } \\
\hline & 1 & 2 & 3 \\
\hline You like to learn English & 0,767 & & \\
\hline You like someone else speaking with you in English & 0,760 & & \\
\hline You like to speak English & 0,729 & & \\
\hline You like to read books, documents and journals in English & 0,717 & & \\
\hline You like watching TV shows in English & 0,668 & & \\
\hline $\begin{array}{l}\text { In general, you realize that learning English is important and you love } \\
\text { learning English }\end{array}$ & 0,662 & & \\
\hline You spend a lot of time learning English. & 0,647 & & \\
\hline $\begin{array}{l}\text { You will enroll an extra English course even if it is not a compulsory } \\
\text { subject in the school }\end{array}$ & 0,495 & & \\
\hline $\begin{array}{l}\text { Being able to communicate with foreigners in English is a fundamental } \\
\text { purpose of learning English. }\end{array}$ & 0,319 & & \\
\hline Being able to speak English is an advantage in the present time & & 0,779 & \\
\hline You need English to be more successful in your studies & & 0,751 & \\
\hline English is an important tool in scientific research & & 0,662 & \\
\hline All students should learn English & & 0,639 & \\
\hline $\begin{array}{l}\text { Learning English is important to you, because English is a very useful } \\
\text { tool in modern society }\end{array}$ & & 0,626 & \\
\hline When someone speaks English, you think they make a good impression. & & 0,562 & \\
\hline Learning English will help to develop your mind. & & 0,521 & \\
\hline Students should regularly use English in communication & & 0,504 & \\
\hline When someone speaks English you think they are good and qualified & & 0,408 & \\
\hline $\begin{array}{l}\text { The important purpose of learning English is to get high score in English } \\
\text { Tests }\end{array}$ & & & 0,822 \\
\hline The important goal for learning English is to get a college degree & & & 0,745 \\
\hline The important purpose of learning English is to have a good job & & & 0,549 \\
\hline You learn English to make good academic progress & & & 0,504 \\
\hline
\end{tabular}

\section{Attitude of student towards learning English}

Student's attitude was evaluated by the mean of the 22 main items of the survey. In which, each statement in the items was evaluated on a 5-level Likert scale (from 1 to 5 ), where value 5 was the most positive (very agreeable), value 1 was the most negative (Very disagree). To draw conclusions about students' attitudes towards the survey factors, agreed on the distribution of the average value of the observed variables is as follows: 1 to 1.8 (very negative); from 1.8 to near 2.6 (negative); From 2.6 to near 3.4 (normal); from 3,4 to 4,2 (positive), from 4,2 to 5 (very positive). 
Table 3. Descriptive analysis

\begin{tabular}{|c|c|c|c|c|c|c|c|c|}
\hline Items & & $\begin{array}{l}\text { Strongly } \\
\text { disagree }\end{array}$ & Disagree & Neutral & Agree & $\begin{array}{l}\text { Strongly } \\
\text { agree }\end{array}$ & Mean & $\begin{array}{l}\text { Std. } \\
\text { deviation }\end{array}$ \\
\hline \multirow{2}{*}{$\begin{array}{l}\text { Learning English is } \\
\text { important to you, } \\
\text { because English is a } \\
\text { very useful tool in } \\
\text { modern society }\end{array}$} & Frequency & 33 & 1 & 10 & 223 & 427 & \multirow[b]{2}{*}{4.46} & \multirow[b]{2}{*}{.926} \\
\hline & $(\%)$ & 4.8 & 0.1 & 1.4 & 32.1 & 61.5 & & \\
\hline \multirow{2}{*}{$\begin{array}{l}\text { When someone speaks } \\
\text { English you think they } \\
\text { are good and qualified }\end{array}$} & Frequency & 12 & 58 & 167 & 380 & 77 & \multirow[b]{2}{*}{3.65} & \multirow[b]{2}{*}{.849} \\
\hline & $(\%)$ & 1.7 & 8.4 & 24.1 & 54.8 & 11.1 & & \\
\hline \multirow{2}{*}{\begin{tabular}{|l|} 
When someone \\
speaks English, you \\
think they make a \\
good impression.
\end{tabular}} & Frequency & 15 & 29 & 113 & 409 & 128 & \multirow[b]{2}{*}{3.87} & \multirow[b]{2}{*}{.833} \\
\hline & $(\%)$ & 2.2 & 4.2 & 16.3 & 58.9 & 18.4 & & \\
\hline \multirow{2}{*}{$\begin{array}{l}\text { Being able to speak } \\
\text { English is an } \\
\text { advantage in the } \\
\text { present time }\end{array}$} & Frequency & 26 & 0 & 8 & 209 & 451 & \multirow[b]{2}{*}{4.53} & \multirow[b]{2}{*}{.850} \\
\hline & $(\%)$ & 3.7 & 0 & 1.2 & 30.1 & 65.0 & & \\
\hline \multirow{2}{*}{$\begin{array}{l}\text { English is an } \\
\text { important tool in } \\
\text { scientific research }\end{array}$} & Frequency & 15 & 7 & 55 & 337 & 280 & \multirow[b]{2}{*}{4.24} & \multirow[b]{2}{*}{.813} \\
\hline & $(\%)$ & 2.2 & 1.0 & 7.9 & 48.6 & 40.3 & & \\
\hline \multirow{2}{*}{$\begin{array}{l}\text { You need English to } \\
\text { be more successful in } \\
\text { your studies }\end{array}$} & Frequency & 20 & 4 & 35 & 317 & 318 & \multirow[b]{2}{*}{4.31} & \multirow[b]{2}{*}{.834} \\
\hline & $(\%)$ & 2.9 & 0.6 & 5.0 & 45.7 & 45.8 & & \\
\hline \multirow{2}{*}{$\begin{array}{l}\text { Learning English } \\
\text { will help to develop } \\
\text { your mind. }\end{array}$} & Frequency & 9 & 25 & 143 & 371 & 146 & \multirow[b]{2}{*}{3.89} & \multirow[b]{2}{*}{.817} \\
\hline & $(\%)$ & 1.3 & 3.6 & 20.6 & 53.5 & 21.0 & & \\
\hline \multirow{2}{*}{$\begin{array}{l}\text { You like to learn } \\
\text { English }\end{array}$} & Frequency & 13 & 36 & 241 & 300 & 104 & \multirow[b]{2}{*}{3.64} & \multirow[b]{2}{*}{.864} \\
\hline & $(\%)$ & 1.9 & 5.2 & 34.7 & 43.2 & 15.0 & & \\
\hline \multirow{2}{*}{$\begin{array}{l}\text { You like to speak } \\
\text { English }\end{array}$} & Frequency & 6 & 40 & 183 & 301 & 164 & \multirow[b]{2}{*}{3.83} & \multirow[b]{2}{*}{.884} \\
\hline & $(\%)$ & 0.9 & 5.8 & 26.4 & 43.4 & 23.6 & & \\
\hline \multirow{2}{*}{$\begin{array}{l}\text { You like someone } \\
\text { else speaking with } \\
\text { you in English }\end{array}$} & Frequency & 15 & 126 & 257 & 227 & 69 & \multirow[b]{2}{*}{3.30} & \multirow[b]{2}{*}{.950} \\
\hline & $(\%)$ & 2.2 & 18.2 & 37.1 & 32.7 & 9.9 & & \\
\hline You like watching TV & Frequency & 7 & 103 & 313 & 212 & 59 & 3 & \\
\hline shows in English & $(\%)$ & 1.1 & 14.8 & 45.1 & 30.5 & 8.5 & 3.31 & .861 \\
\hline You like to read & Frequency & 10 & 149 & 333 & 162 & 40 & & \\
\hline $\begin{array}{l}\text { books, documents } \\
\text { and journals in } \\
\text { English }\end{array}$ & $(\%)$ & 1.4 & 21.5 & 48.0 & 23.3 & 5.8 & 3.11 & .852 \\
\hline All students should & Frequency & 18 & 16 & 56 & 327 & 277 & 410 & \\
\hline learn English & Percent (\%) & 2.6 & 2.3 & 8.1 & 47.1 & 39.9 & 4.19 & .877 \\
\hline Students should & Frequency & 14 & 31 & 135 & 358 & 156 & & \\
\hline $\begin{array}{l}\text { regularly use English } \\
\text { in communication }\end{array}$ & $(\%)$ & 2.0 & 4.5 & 19.5 & 51.6 & 22.5 & 3.88 & .875 \\
\hline
\end{tabular}




\begin{tabular}{|c|c|c|c|c|c|c|c|c|}
\hline \multirow{2}{*}{$\begin{array}{l}\text { You will enroll an } \\
\text { extra English course } \\
\text { even if it is not a } \\
\text { compulsory subject } \\
\text { in the school }\end{array}$} & Frequency & 18 & 32 & 86 & 395 & 163 & \multirow[b]{2}{*}{3.94} & \multirow[b]{2}{*}{.880} \\
\hline & $(\%)$ & 2.6 & 4.6 & 12.4 & 56.9 & 23.5 & & \\
\hline \multirow{2}{*}{$\begin{array}{l}\text { You learn English to } \\
\text { make good academic } \\
\text { progress }\end{array}$} & Frequency & 12 & 72 & 168 & 341 & 101 & \multirow[b]{2}{*}{3.64} & \multirow[b]{2}{*}{.913} \\
\hline & $(\%)$ & 1.7 & 10.4 & 24.2 & 49.1 & 14.6 & & \\
\hline \multirow{2}{*}{$\begin{array}{l}\text { The important goal for } \\
\text { learning English is to } \\
\text { get a college degree }\end{array}$} & Frequency & 52 & 278 & 157 & 180 & 27 & \multirow{2}{*}{2.79} & \multirow{2}{*}{1.035} \\
\hline & $(\%)$ & 7.5 & 40.1 & 22.6 & 25.9 & 3.9 & & \\
\hline \multirow{2}{*}{$\begin{array}{l}\text { The important } \\
\text { purpose of learning } \\
\text { English is to have a } \\
\text { good job }\end{array}$} & Frequency & 16 & 24 & 77 & 407 & 170 & \multirow[b]{2}{*}{4.00} & \multirow[b]{2}{*}{.838} \\
\hline & $(\%)$ & 2.3 & 3.5 & 11.1 & 58.6 & 24.5 & & \\
\hline \multirow{2}{*}{$\begin{array}{l}\text { The important purpose } \\
\text { of learning English is } \\
\text { to get high score in } \\
\text { English Tests }\end{array}$} & Frequency & 30 & 140 & 236 & 238 & 50 & \multirow[b]{2}{*}{3.20} & \multirow[b]{2}{*}{.984} \\
\hline & $(\%)$ & 4.3 & 20.2 & 34.0 & 34.3 & 7.2 & & \\
\hline \multirow{2}{*}{$\begin{array}{l}\text { Being able to } \\
\text { communicate with } \\
\text { foreigners in English is } \\
\text { a fundamental purpose } \\
\text { of learning English. }\end{array}$} & Frequency & 10 & 28 & 87 & 392 & 177 & \multirow[b]{2}{*}{4.01} & \multirow[b]{2}{*}{.820} \\
\hline & $(\%)$ & 1.4 & 4.0 & 12.5 & 56.5 & 25.5 & & \\
\hline \multirow{2}{*}{\begin{tabular}{|l} 
You spend a lot of \\
time learning \\
English. \\
\end{tabular}} & Frequency & 10 & 77 & 428 & 155 & 24 & \multirow{2}{*}{3.15} & \multirow[b]{2}{*}{.713} \\
\hline & $(\%)$ & 1.4 & 11.1 & 61.7 & 22.3 & 3.5 & & \\
\hline \multirow{2}{*}{\begin{tabular}{|l|} 
In general, you \\
realize that learning \\
English is important \\
and you love \\
learning English \\
\end{tabular}} & Frequency & 9 & 9 & 152 & 357 & 167 & \multirow[b]{2}{*}{3.96} & \multirow[b]{2}{*}{.792} \\
\hline & $(\%)$ & 1.3 & 1.3 & 21.9 & 51.4 & 24.1 & & \\
\hline \multicolumn{7}{|c|}{ Attitude } & 3.7678 & .43468 \\
\hline \multicolumn{7}{|c|}{ Cognitive } & 4.1428 & .55572 \\
\hline \multicolumn{7}{|c|}{ Behavioral } & 3.4063 & .65676 \\
\hline \multicolumn{7}{|c|}{ Emotional } & 3.5616 & .57557 \\
\hline
\end{tabular}

Statistical results (see Table 3) show that the mean value of attitudes toward English learning of 694 respondents in the survey was 3.77 (standard deviation of 0.43 ). This data shows that students have a positive attitude towards learning English. In addition, the mean of the three components of attitudes including cognitive, emotional and behavioral was positive, with the cognitive component achieving the highest value of 4.14 (the standard deviation is 0.55 , followed by the emotional component of 3.56 (standard deviation of 0.57) and the behavioral component of 3.4 (standard deviation of 0.65 ).

Around $61.5 \%$ of respondentsagreed with the statement that "learning English is important because it's a very useful tool in modern society". The majority of respondents (95\%) agreed with the statement that "speaking English is an advantage in the present time". $88.9 \%$ of the students in the sample agree and strongly agree with the statement that English is 
an important tool in scientific research. $99.5 \%$ of the students in the sample agree and strongly agree with the English speech to help them succeed in their studies. $47.1 \%$ of all students should learn English, 39.9\% would agree. $74.1 \%$ agreed and very much in line with the statement that students should regularly use English in communication. 83.1\% of respondentsagreedand strongly agreed with theitem "the purpose of learning English is to have a suitable job". $82 \%$ of respondents agreed and strongly agreed with the statement that the basic purpose of learning English was to be able to communicate with foreigners.

At the same time, the figures also show that the students in the sample appreciated English speakers. Specifically, $54.8 \%$ agreed, $11.1 \%$ strongly agreed that when someone speaks English, they are good and qualified. In addition, $58.9 \%$ agreed and $18.4 \%$ strongly agreed that speaking English would make a good impression. However, $18.2 \%$ of the students in the sample did not like others talking to themselves in English. $14.8 \%$ did not like watching TV shows in English. $21.5 \%$ do not like to read more books, documents, magazines in English. 11.1\% disagree with the statement "you spend a lot of time learning English”.

\section{Conclusion}

From the results of the analysis above, we can conclude that most students are aware of the importance of English in their studies and in future career development. However, there is still a gap between awareness, attitude and their actions. Therefore, furtherstudies should be conducted to develop more understanding of students' attitudes towards learning English and the factors that may affect their learning achievement.

\section{References}

[1] Allport, G.W. (1935) Attitudes. In: Murchison, C., Ed., A Handbook of Social Psychology, Clark University Press, Worcester.

[2] Baker, C. (1992). Attitudes and language. Clevedon Hall: Multilingual Matters.
[3] Bem, D.J. (1970). Beliefs, attitudes, and human affairs. Belmont, CA: Brooks/Cole.

[4] Crystal, D. (1997). A Dictionary of Linguistics and Phonetics (4th ed.). UK.

[5] Eagly, A. H. (1993). The psychology of attitudes. Fort Worth, TX: Harcourt Brace Jovanovich.

[6] Fakeye, D. (2010). Students' Personal Variables as Correlates of Academic Achievement in English as a Second Language in Nigeria. Journal of Social Sciences, 22(3), 205-211.

[7] Gardner, R. (2008). Individual Differences in Second and Foreign Language Learning. (N. D.S. Hornberger, Ed.) Encyclopedia of Language and 213 Education, 4. [Second and Foreign Language Education], pp. 29-40.

[8] Gömleksiza, M. N. (2010). An evaluation of students' attitudes toward English language learning in terms of several variables. Procedia Social and Behavioral Sciences, 9 (2010), 913918.

[9] Hilgard, E. R. (1980). The trilogy of mind: Cognition, affection, and conation. Journal of the History of the Behavioral Sciences, 107-117.

[10] Latchanna, G. \& Dagnew, A. (2009). Attitude of teachers towards the use of active learning methods. E-journal of All India Association for Educational Research, 21(1).

[11] Lennartsson, F. (2008). Students' motivation and attitudes towards learning a second language: British and Swedish students' points ofview. http://urn.kb.se/resolve?urn=urn:nbn:se:vx u:diva-2571.

[12] Mamun, S. A. (2012). Students' Attitudes towards English: The Case of Life Science School of Khulna University. International Review of Social Sciences and Humanities, Vol. 3, No. 1 (2012), 200-209.

[13] Rajecki, D. W. (1982). Attitudes, Themes and Advances. Sinauer Associates.

[14] Rukh, S. (n.d.). Students' attitudes towards English language learning and academic achievement: A case of business students in Punjab. European Academic Research, 2(4), 5596-5612.

[15] Triandis, H. (1971). Attitude and attitude change. New York: John Wiley.

[16] Wenden, A. ( 1991). Learner strategies for learner autonomy. London: Prentice Hall. 